\title{
Bacterial Spores: Mechanisms of Stability and Targets for Modern Biotechnologies
}

\author{
Andryukov BG ${ }^{1,2 *}$, Karpenko AA ${ }^{3}$, Lyapun IN ${ }^{1}$, Matosova EV ${ }^{1}$ and Bynina MP $^{1}$ \\ ${ }^{1}$ Somov Institute of Epidemiology and Microbiology, Russia \\ ${ }^{2}$ Far Eastern Federal University, Russia
}

${ }^{3}$ A.V. Zhirmunsky Institute of Marine Biology, National Scientific Center of Marine Biology, Far Eastern Branch, Russian Academy of Sciences (NSCMB FEB RAS), Vladivostok, Russia

*Corresponding author: Andryukov Boris G, Somov Institute of Epidemiology and Microbiology, Far Eastern Federal University

(FEFU), School of Biomedicine, Vladivostok, Russia

\section{ARTICLE INFO}

Received: 慧 August 09, 2019

Published: 幽 August 21, 2019

Citation: Andryukov BG, Karpenko AA, Lyapun IN, Matosova EV, Bynina MP. Bacterial Spores: Mechanisms of Stability and Targets for Modern Biotechnologies. Biomed J Sci \& Tech Res 20(5)-2019. BJSTR. MS.ID.003500

Keywords: Bacterial Spores; Endospores; Exospores; Sporulation; Structure; Atomic Force Microscopy (AFM); Raman Spectroscopy (RS); Modern Biotechnologies

\begin{abstract}
Some gram-positive bacteria of the genus Bacillus spp. and Clostridium spp. can exist in two alternative states: vegetative and in the form of endospores, which are divided into two types: having an outer shell (exosporium) and not having it. Bacterial controversies have been studied for a long time and yet they remain not fully recognized as objects of the microworld. These resting (dormant) cells, recognized as the most stable form of life on Earth, are formed in the mother cell with a lack of nutrients. The extraordinary resistance of spores to extreme physical and chemical conditions of existence is the main distinguishing feature from vegetative forms, and their life cycle contributes to the wide spread of spore-forming bacteria in various ecosystems. The unique properties of bacterial spores cause increased scientific and medical interest associated with the epidemiological significance of resting cell forms that can be in a metabolically inactive state for tens and hundreds of years. As soon as spores get into human or animal organisms, as well as into canned foods, they germinate and become a source of serious infectious diseases. Spores are an infectious form of spore-forming bacteria, among which the most dangerous are B. anthracis (anthrax causative agent), B. cereus (toxicoinfection), as well as representatives of the genus Clostridium - C. botulinum (botulism), C. perfringens (gas gangrene), and $C$. difficile (nosocomial infections). The relevance of the research and the prospectiveness of the study of spores mediates the need to disclose their biochemical structure, molecular mechanisms of steadiness, as well as detection and indication using modern analytical tools. The characterized supramolecular structures of endo- and exospores become a target for modern biotechnologies on the principle of "learning from Nature". These biological systems are perspective models for packaging and targeted delivery of enzymes, nucleic acids, antigens and drugs to specific tissues, cells and even intracellular organelles for the treatment of cancerous tumors and the creation of thermostable vaccines. The unique properties of bacterial spores will soon find application in ecosystem technologies as biofungicides and bioinsecticides in
\end{abstract}

\section{Introduction}

Most microorganisms are widely classified into gram-negative and gram-positive categories, based on the presence of an external membrane and the thickness of the peptidoglycan layer. In the event of extreme environmental conditions, some gram-positive bacteria, which include the majority of microorganisms pathogenic to humans, form extremely stable bodies of a spherical or elliptical shape - spores. The nucleation and maturation inside the mother cell gave reason to call them endospores. It is recognized that bacterial spores are the most stable form of life on Earth [1,2]. They fulfill the important function of preserving the bacterial population from extreme environmental influences and are a key factor in the virulence of infectious agents. In some pathogenic species of Bacillus spp. and Clostridium spp. endospores are independent infectious agents [3-5]. 
The fight against bacterial spores of pathogenic bacteria in medical institutions is also an acute problem associated with the prevention of nosocomial infections $[3,6,7]$. In particular, some pathogenic species of Clostridium spp. (eg, C. difficile) are the most common causative agent of nosocomial infections on the planet [8-11]. Among the detected endospores, two categories were identified: those that are enclosed in a spherical outer shell (exospore, exosporium), and which do not have this structure. In contrast to the well characterized endospores, knowledge of the role and structure of exosporia is less distinct [5,12-14].

The relevance of studying the listed functions of bacterial spores in the epidemiology and pathogenesis of dangerous infections is associated with the study of their spatial organization, as well as the molecular mechanisms of the formation of dormant resistance. This is important for the development of new sterilization and detection strategies, as well as the use of these unique biological systems as promising models for modern biotechnologies $[8,15]$.

\section{Spore Formation in Gram-Positive Bacteria}

Endospore: A dormant, non-metabolic, and nonreproductive structure. The ability of microorganisms to spore formation was one of the key characteristics of their early classification [16]. Sporulation, on the one hand, is a form of a bacterial reaction to environmental changes, and on the other hand, a strictly regulated sequence of stages of gene expression and the process of cellular morphological differentiation. As a result of spore formation, metabolically inactive cellular forms (dormants) are formed, the morphology of which is radically different from the maternal vegetative cell [17-19].

The formation of spores is one of the manifestations of the numerous mechanisms of adaptation of microorganisms to carbon and nitrogen starvation, but unlike other adaptive strategies of bacteria, the formation of endospores lasts on average about 8 hours and proceeds in several stages [20-22]. Bacterial spores are extraordinary resistant to extreme environmental factors, such as a complete lack of nutrients, exposure to antibiotics, disinfectants, antibacterial strategies of the host's immune system, high temperature and pressure, ultraviolet radiation, radiation, and for a long time they are can remain viable $[13,21,23,24]$.

\section{Sporulation Regulation}

Sporulation, as a rule, begins in the stationary phase of the vegetative cell cycle, is initiated by the depletion of nutrients, and is a morphogenetic process of assembly of supramolecular structures inside the cytoplasm of a vegetative cell (sporangia). The formation of spores begins with a signal for the vegetative cell to start a cascade of synthesis of transcription factors that control the sporulation stages. This transformation is accompanied by successive and significant changes in the morphology, biochemistry, and physiology of bacteria and culminates in the transformation of a vegetative cell into a resting form [11,25-28].

At the beginning of the XXI century, it became apparent that many bacterial reactions to environmental conditions are regulated by the so-called multicomponent molecular genetic systems [16,29-31]. One of these systems, in response to food stress, triggers the activation of sporulation genes, among which the key is spo0A, which encodes the synthesis of Spo0A protein [22,32,33]. The phosphorylated form of this protein (Spo0A P), in turn, initiates the expression of about two hundred sporulation genes (for example, spoIIE, sigH, ftsZ and others), starting the hours-long process of endospore formation. One of the genes expressed by SpoOA P is sigH (spoOH), which encodes the synthesis of sporespecific sigma transcription factors $\sigma \mathrm{H}$ and $\sigma \mathrm{F}$, which control the sporulation stages [12,33-35].

As a result, a vegetative cell undergoes a complex, but clearly defined sequence of morphological and biochemical events, which ultimately lead to the formation of mature endospores (Figure 1). After completion of spore formation, the mother cell undergoes programmed autolysis, releasing a mature spore into the environment [36].

\section{Heat Resistance of Endospores and Dipicolinic Acid (DPA)}

The extreme resistance of endospores to extreme environmental conditions is still under study. However, the mechanism of their heat resistance, apparently, is one of the most complexes. Mature endospores are in a state of reproductive and metabolic rest, reduced enzymatic activity and low content of high-energy compounds (ATP and NADH). The presence of several additional membranes compared to a vegetative cell is a barrier against the penetration of water and substances dissolved in it. Dehydration protects the inside proteins from denaturation and irreversible aggregation at extremely high temperatures, which mediates the ability of spores to survive for a long time (tens, hundreds or more years) without a supply of nutrients under conditions when vegetative cells die [19,37-39].

Heat resistance of endospores is key mechanism of to their survival and preservation of the bacterial population. As a rule, to ensure reliable sterilization of medical devices, heat treatment of $110^{\circ} \mathrm{C}$ for $20 \mathrm{~min}$ is recommended (steam method) or $120^{\circ} \mathrm{C}$ for $45 \mathrm{~min}$ (dry air method). However, studies conducted by $\mathrm{R}$. Scheldeman (2006) and W. Schubert (2011) with colleagues showed that endospores can survive after standard thermal sterilization methods, and special heat treatment regimens are necessary for their destruction $[40,41]$ 


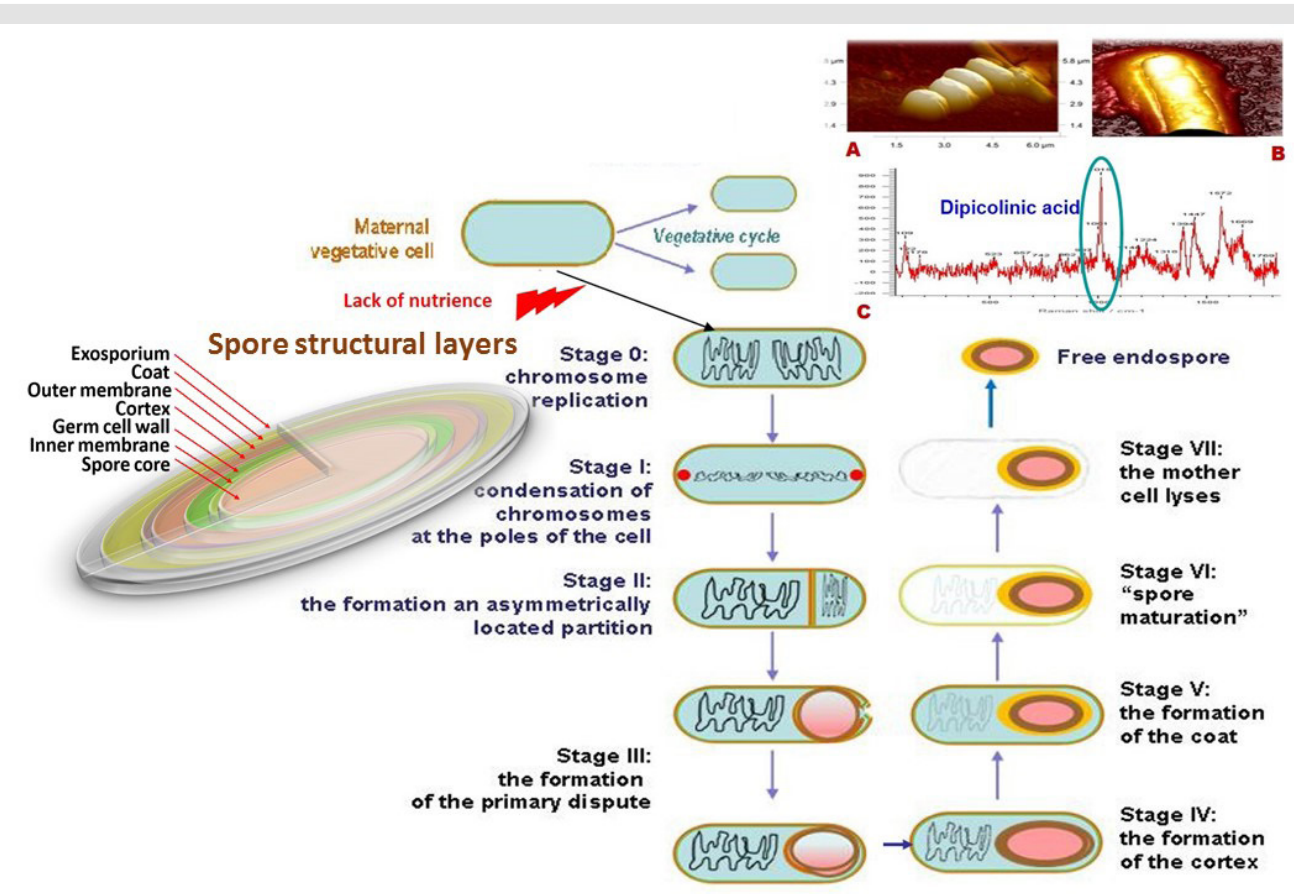

Figure 1: The sequence of morphological changes occurring at different stages of sporulation in gram-positive bacteria: initiation of sporulation by nutrient deficiencies, replication of chromosomes (stage 0 ); the formation of an axial thread of chromatin and condensation of chromosomes at the poles of the cell (stage I); stage II - the formation of an asymmetrically located partition that creates two compartments and separation of nuclear material; stage III - the formation of the primary dispute and sporangia; stage IV - spore bark formation; differentiation of prospore and sporangia; stage $\mathrm{V}$ - formation of the outer spore shell; stage VI - spore maturation; stage VII - maternal cell autolysis and spore release. A and B - visualization of the spore using atomic force microscopy (Bacillus subtilis, ATCC 6633); C - detection of dipicolinic acid using RAMAN spectroscopy (photos and images by the authors).

High heat resistance of endospores is provided by dipicolinic (pyridine-2,6-dicarboxylic) acid (DPA), which forms a chelate complex with calcium and other divalent cations and reduces the water content in spores to a very low level $[21,39,42,43]$. DPA accounts for up to $15 \%$ of the total endospore mass and is not found in vegetative cells $[7,19,21,38,44,45]$. Despite the fact that DPA was found in bacterial spores quite a long time ago [43], the function of this interesting chemical structure has been not finally determined $[19,44,45]$. The high concentration of dipicolinic acid and its specificity for bacterial endospores have made this component the main object of scientific research. At the beginning of the XXI century A. Driks (2003) and P. Setlow (2006) suggested that this acid, intercalated with DNA and RNA via covalent bonds, forms a gel-like polymer matrix that protects nucleic acids from damage at high temperatures $[31,46]$.

The leading role of DPA in ensuring dehydration [37], creating and maintaining metabolic rest [7], as well as stabilization of basic nuclear proteins undisputed [38,44] and minimizing the likelihood of their denaturation, aggregation, and lysis $[7,37,38,44]$ is indisputable. During germination, DPA is released from spores, providing the reverse process of hydration of the nucleus and the formation of vegetative cells $[19,37]$. The unique properties of DPA of endospores have allowed modern biotechnologists to consider it as a promising excipient (excipient) to increase the stability and highly effectiveness of biopharmaceutical liquid protein preparations and prevent their non-specific aggregation, for example, antibodies [38].

\section{Endospore Morphology}

Morphological observations of the changes occurring at the stages of sporulation showed that the formation of the spatial structure of the spore membranes begins with the process of invagination of the cytoplasmic membrane and the final separation of the prospores from the mother cell. The mature endospore has a concentric multilayer structure, while the number of protein layers varies in different types of bacteria. Its main structural components are the core surrounded by two layers of structurally distinct peptidoglycans in the inner shell, which is characterized by low permeability for small molecules and water $[16,25,51]$, and cortical peptidoglycan [27].

Cortical peptidoglycan structurally corresponds to a similar cell wall polymer of a vegetative cell. The main difference is the presence of modified muramiko- $\delta$-lactam and peptide crosslinks between glycan chains $[21,44,52,53]$. The nucleus is located inside the dehydrated cytoplasm, contains nucleic acids and sporespecific compounds: dipicolinic acid, divalent metal ions $\left(\mathrm{Ca}^{2+}\right.$, $\mathrm{Mn}^{2+}$ and $\mathrm{Mg}^{2+}$ ) and Small Acid-Soluble Proteins (SASP) with a molecular weight of up to $12 \mathrm{kDa}$, up to $20 \%$ of the total number of sporoproteins $[17,19,34,37]$. 
These proteins, functioning as a molecular barrier, protect spores from ultraviolet radiation and active oxygen radicals $[17,54,55]$ and serve as a source of amino acids for spores during their germination period $[7,55]$. Thanks to the use of mass spectrometry in the outer shell, more than 70 different proteins were found that are difficult to separate due to chemical crosslinking that protects endospores from the destructive effects of hydrolytic enzymes and strengthens the structure of the shell. The assembly and arrangement of these protein structural components of endospores ensures their survival and preservation in anticipation of suitable conditions for germination $[7,21,56,57]$.

\section{Endospore Germination}

Scientific and practical interest in disputes is caused not only by their biochemical structures mediating molecular stability strategies, but also by the mechanisms of regulation of their transformation into vegetative forms under favorable conditions. Such conditions occur when spores enter humans or animals, where they germinate and become pathogens of dangerous infections. For example, due to the germination of $B$. anthracis spores in lung macrophages, a pulmonary anthrax form $[26,58,59,60]$.

Like sporulation, spore germination is an equally complex and strictly regulated process that proceeds in several stages $[37,45,61]$. Spore germination in nature is initiated by nutrients (amino acids, carbohydrates, purine nucleosides, or combinations thereof). Nutrient substrates interact with the receptors of the inner membrane of the spores and start the germination program, which at some point becomes irreversible. The program begins with the release of dipicolinic acid, hydrogen ions and divalent cations and their replacement with water, which causes an increase in the $\mathrm{pH}$ of the core from 6.5 to 7.7 and the hydrolysis of the peptidoglycan bark.

These changes are important for the subsequent increase in enzymes activity and, ultimately, the metabolism of future cells, accompanied by macromolecular synthesis. In this case, the spore swells and grows in size not only as a result of water absorption, but also as a result of cell growth due to reserve material $[5,14,45,62]$. Farther, the membranes break under the influence of pressure caused by growth, and a new vegetative cell emerges from the destroyed spore membrane [57]. Partially based on this germination mechanism, a fractional sterilization method is based. Even if the spore has not grown, but hydration has occurred, the process is irreversible; she must first become a vegetative cell $[45,56]$. For the germination of endospores, the external glycoprotein membranethe exosporium (exospore), which provides their connection with the environment, is of particular importance.

\section{Exosporium: Molecular determinants on the Surface of Endospores}

The Spatial Organization of Exospores: As already mentioned, in some endospores of spore-forming gram-positive bacteria, an additional outer protein layer, the exosporium, forms a barrier to the environment during sporulation $[3,18,63,64,65]$. In recent years, studies of exosporium have been carried out mainly on isolates of three main closely related species of spore-forming bacteria (Firmicutes type) included in the Bacillus cereus sensu lato group: B. anthracis (anthrax causative agent), and B. cereus (foodborne infectious agent) and $B$. thuringiensis (bacterial insecticide) $[13,66,67,68]$. In addition to them, exospores form some species of Clostridium spp. $[9,12,69-73]$.

The exospore architectures of bacteria in these groups have a similar morphology [13]. Usually they are a flexible, but strong shell - a thin continuous protein basal layer, which has an outer, hair, and inner, crystalline layers. The subtle features of exosporia can vary under different growth conditions and in different types of bacteria [68,74-79].

The use of modern methods of molecular biology has significantly expanded the understanding of the biochemical structure and spatial organization of the exosporial structures of the Bacillus spp family and Clostridium spp. (Figure 2). The exosporium of these bacteria is a thin and flexible shell structure, which is usually much larger than the dense endospore located inside $[5,14]$.

The main structural element of exospores in different types of bacteria is a thin crystalline basal protein layer $[12,13,80]$. The outer surface of the basal layer has a hairy coating ("hairy nap"), which is represented by collagen-like filaments in the exosporium of bacteria of the group $B$. cereus sensu lato protein $\operatorname{BclA}[12,78,79,81,82]$. It turned out that this glycoprotein plays a significant role in protecting spores from phagocytosis $[21,78,79]$. In addition, it was recently shown that it mediates the mechanism of immune inhibition, which contributes to the preservation of spores in the lungs of mice $[1,83]$. The region between the basal layer of the exosporium and the outer shell of the endospore is called the intermediate space $[26,60]$ and is approximately $500 \mathrm{~nm}$ [67]. In some places, the basal layer is located in close proximity to the outer layer of the endospore membrane. The exosporium basal layer has a thickness of approximately 12 to $16 \mathrm{~nm}$ and consists of two sublayers approximately $5 \mathrm{~nm}$ thick $[26,67]$.

The basal layer has a crystalline structural organization with 6 -fold symmetry and a periodic interval of $7 \mathrm{~nm}$. The outer surface of this structure consists of a series of hexagonal concave cups in the form of honeycombs, with open ends oriented outwards [17]. Semi-permeable channels with a diameter of 20 to $34 \AA$ are located between the cups $[17,84,85]$, which is sufficient for the penetration of low molecular weight substances, but too small for the diffusion of large molecular proteins. This channel structure provides the barrier properties of exosporia $[17,67,84]$.

Hairy filaments of exospore, usually consisting of BclA protein, have a length of 14 to $70 \mathrm{~nm}$ and cover the entire surface of the 
outer shell of the basal layer $[67,81,82,86,87]$. Recent studies have shown that, unlike other bacteria of the $B$. cereus sensu lato group, in the B. megaterium exosporium (strain QM B1551), nap filaments were localized at only one pole and consisted of ortholog proteins BclA and BclB, as well as BxpB protein (ExsFA) [55,88-91].

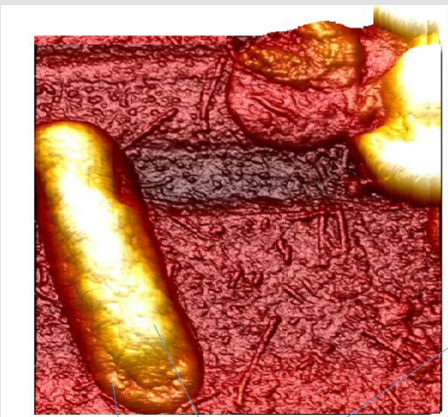

A

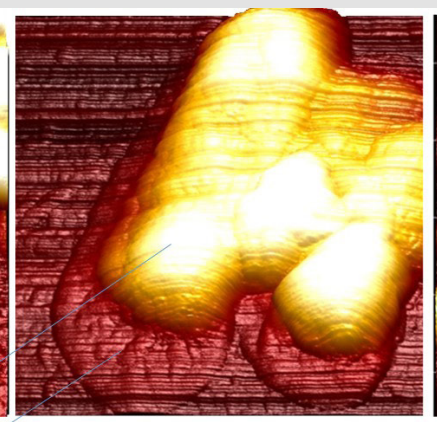

B

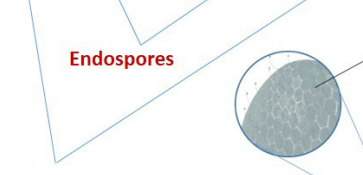

Hexagonal honeycomb Hexagonal honeycomb
of the outer surface basal layer

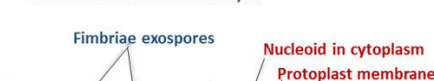

Protoplast membrane

Exospores

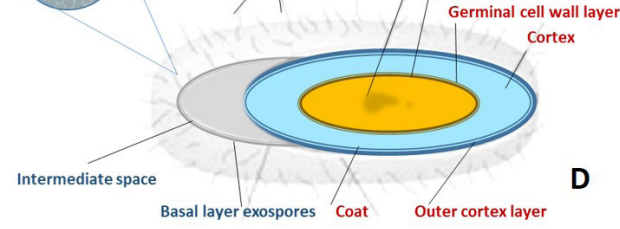

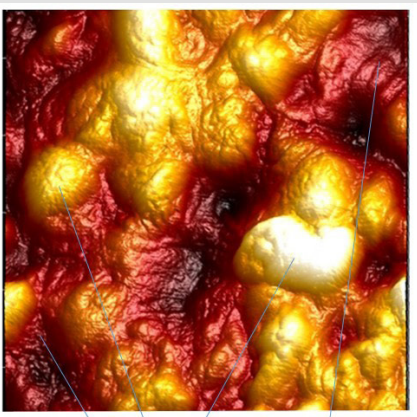

C

Endospores

Figure 2: AFM visualization and schematic representation of endo- and exospores: $A$ - exospores of B. cereus, strain XXXX; B - exospores of B. cereus, ATCC 11778; C - exospores of B. cereus, AACC 14579 (atomic force microscopy); D - structural organization of endo- and exospores (photos and images by the authors).

Synthesis of Exosporium and its Biochemical Structure. The biochemical structure of exosporium, which differs significantly from the structure of endospores, has been the subject of many reviews [13,26,88,92]. The general process of exosporium biosynthesis is illustrated by the conceptual model of "bottle cap" and includes two stages with respect to B. anthracis [60,75,92-94]. The initiation of synthesis occurs at the central pole of the spore. First, the embryo of the future exospore appears in the form of a small layered structure in the spore-forming mother cell. The exospore is assembled by subsequent precipitation of proteins, and starts from the synthesis of the "cap" - the area located near the central pole of the maternal spore, which includes approximately $25 \%$ of the surface of the basal layer, and ends with the formation of the remaining "non-cap" ("bottle") part of the exosporium (about $75 \%$ ). The synthesis ends at the opposite pole of the spore after attaching the basal layer of the exospore to the outer shell of the spore. Studies conducted in recent years on B. anthracis and $B$. cereus strains have shown that a number of proteins take part at different stages of biosynthesis of individual exosporium regions, which ultimately mediates its complex biochemical structure $[25,55,67,95]$.

In the study of mutant isolates of B. anthracis J.A. Boydston et al. and C.T. Steichen et al. for the first time, it was found that the basal layer of exosporia is not a biochemically homogeneous structure - they differ in protein composition [23,74]. For example, CotY is a cap-specific protein, while the proteins BclB, ExsY, BhrB (also known as ExsFA), ExsFB, and BclA are specific for the rest of the exosporium $[23,89,91]$. Of these proteins, CotY and ExsYare involved in exosporia biosynthesis at the initial stages of the formation of the basal layer base, while ExsFA and ExsFB - at the final stages [74,88]. Moreover, ExsFA (exosporium protein weighing $17 \mathrm{kDa}$ ) is found both in the "cap" region and outside it, while its analogue, BxpB, is found (mainly) in the "non-cap" part of exosporium [82,90,92]. Both of these proteins (some authors put an equal sign between them) are necessary at the stage of formation of filaments of the fleecy layer $[23,67,82,90]$.

Among the proteins involved in the biosynthesis of exosporium, BclA glycoprotein deserves special attention. C. Steichen et al. and T.N. Brahmbhatt et al. using a model of the recombinant glycosylated BclA protein of B. anthracis isolate, it was found that this glycoprotein provides the general hydrophobicity of exospores [92] and also has immunogenic properties [77], which determines the potential opportunity use of BclA for the development of anthrax vaccine. In the experiments, the specific rBclA antigen enhanced the protection of mice infected with B. anthracis spores, activating phagocytosis and simultaneously inhibiting the ability of spore germination inside macrophages, which is known to be the key mechanism of anthrax pathogenesis $[77,87,88,92]$.

The exospore attaches to the outer layer of the endospore membrane through interactions of the interdimensional proteins CotY, ExsA, ExsB, ExsY, and ExsM with the endospore protein CotE $[14,35,66,74,88]$. The same proteins determine the biochemical structure of the exosporium [66,93-95]. When considering the sequence of stages of exosporium biosynthesis, the temporal 
dynamics of the appearance of specific glycoproteins and their inclusion in the process is of interest. The first, approximately 4-5 hours after the start of sporulation, in the cytoplasm of the mother cell are the BclA and BxpB proteins that are involved, as mentioned above, in the synthesis of fleecy coatings. In addition, BxpB glycoprotein is the main protein of the basal layer. These proteins first appear as a high molecular weight protein complex, the assembly of which occurs in the cytoplasm of the mother cell (sporangia) long before these proteins are located in places of developing exosporium. The appearance of these proteins in the sporulating cell in the form of monomers occurs an hour before the start of exosporia biosynthesis [89]. The subsequent involvement of the BclA monomer includes the steps of its covalent binding to the protein of the basal layer of $\mathrm{Bxp} B$ and subsequent glycosylation $[89,90]$. It is of interest that the BclA- and BxpB-containing protein complexes have a similar molecular weight, and the protein protein bonds in them are stable upon boiling in the presence of $1 \%$ SDS, $8 \mathrm{M}$ urea and reducing agents $[89,91]$

J. Manetsberger et al. (2015 and 2018) investigated the role of orthologs of the B. subtilis CotW and CotX proteins encoded by the cotW and cotX plasmid genes in the B. megaterium exosporium $[20,55]$. These proteins form part of the outermost layer of B. subtilis spores, the so-called cortex, which possibly represents a vestigial exosporium structure in this bacterial species $[62,96]$. It was revealed that these proteins are a key component of the basal layer of the B. megaterium exosporium and in their structural role correspond to the CotY proteins and its ExsY paralogue (absent at $B$. megaterium) in the exosporia of $B$. cereus and B. anthracis $[74,88,95]$.

However, the complexity of the biochemical structure of exosporia does not end there. Previous studies conducted by V.M. Thompson et al. (2011 and 2012), showed that the basal layer consists of two (and possibly more) sublayers - the inner (early) one, consisting of two glycoproteins CotY ("cap" region) and ExsY ("non-cap" region), and later (external), consisting mainly of WhpB and ExsFB proteins [90,91]. Exosporium structural proteins determine its properties [45]. The outer surface of the basal layer consists mainly of BclA glycoprotein, which plays a major role in protecting spores from macrophages $[84,87]$. Recently, it was shown that this protein mediates the mechanism of immune inhibition [86,97], which experimentally contributed to the preservation of spores in the lungs of mice. Enzymes that make up exospores, inosine hydrolase, and alanine racemase [85,88,94] can inhibit premature spore germination $[98,99]$. However, the main protein that determines the structure of endosporium a long time was unknown.

S. Jiang et al. (2015) and Terry et al. (2017) based on the results obtained by electron crystallography, it was concluded that the ExsY protein is critical in the formation of the exosporium crystal lattice and the main structural component of its basal layer $[28,63]$. According to the authors, the same protein determines the hexagonal crystal structure of exosporium by disulfide binding of cysteine residues within individual ExsY polypeptide chains and its subunits $[18,28,63]$

These disulfide bonds underlie the ability of ExsY and its homolog CotY to self-assemble into an ordered crystal lattice of high symmetry for stable assembly of exosporia in all species of Bacillus spp. and Clostridium spp. - strong and flexible, capable of forming folds to increase adhesion to the surface $[74,88]$. As is known, adhesion is an important factor of virulence in these types of bacteria $[8,9,17]$. It would seem that the question of basic proteins, which determines the structure of exosporium, is closed, however, in 2018 P. Calderón-Romero et al. conducted interesting studies of exospores on a model of one of the species Clostridium spp. (C. difficile), which, as mentioned above, is currently the leading cause of nosocomial infection in the world [10].

They found that during sporulation, all analyzed $C$. difficile strains formed two morphological types of exosporia:

a. Spores with a thin layer of exosporia; and

b. Spores with a thick exosporium layer $[9,10,74,69,70]$.

Despite the lack of experimental evidence, the authors suggested that each morphotype apparently plays a different role in the pathogenesis of the infection associated with $C$. difficile [10 $69,70]$. It is noteworthy that, despite the ultrastructural differences, the outer fleecy layer was found in both exospore morphotypes $[9,10,69]$. The same group of researchers, using a gel-free approach for analysis of the exosporium layer and combined extraction methods, revealed the presence of 184 proteins in the exosporium layer $[10,70]$. Some of the identified proteins were found to be immunogenic (BclA, CdeC, $\mathrm{CdeM}$, CotA, CotCB, and CotE), and were identified as potential antigenic substances for creating vaccines [65,70 99-101].

In this group of proteins, special attention was paid to collagenlike exospore BclA proteins, which form hair filament structures $[69,70,73]$. C. difficile genomes (bcla1, bcla2, and bcla3) encode three collagen-like BclA paralogs (BclA1, BclA2, and BclA3) [65], which are localized exclusively in the $C$. difficile exospore [10]. Given the fact that BclA2 and BclA3 are widely present in most strains of these bacteria, it is possible that vaccines developed on their basis can provide immune protection against clinically significant isolates.

It was found that cysteine-rich proteins $\mathrm{CdeC}$ and CdeM $C$. difficile are involved in the assembly of the exospore spore layer $[10,32,64]$, while CdeM is unique for this species of clostridia [10], while CdeC protein was found in several members of the bacterial family Peptostreptococcaeace [32]. The absence of these proteins reduces the pathogenicity of $C$. difficile [10]. These proteins are structural and turned out to be highly immunogenic $[32,64,102,103]$. Experimental data indicate that they are of interest for immune biotechnologies as potential antigens for the 
development of new types of vaccines. For example, immunization of mice with CdeM protein demonstrated an IgG-specific immune response [103]. In CdeM-vaccinated mice, protective efficacy of $90 \%$ was achieved after contamination of $C$. difficile. Vaccination of hamsters with the CdeM protein of the recombinant strain 630 C. difficile showed an efficiency of $80 \%[102,103,104]$. This is striking given that the CdeM protein is unique to $C$. difficile. Further experiments, for example, with the inclusion of adjuvants in the composition of the CdeM vaccine in order to more quickly form a pronounced and long-lasting specific immune response, may increase its protective effect [102,105-109].

Immunization of mice with cysteine rich $\mathrm{CdeC}$ protein caused a significant IgG immune response after three immunizations with IP recombinant $\mathrm{CdeC}$ [103]. It was found that $\mathrm{CdeC}$ is an immunogenic protein $[3,64]$. The protective efficacy of CdeC-vaccinated mice was $100 \%$ after infection with C. difficile (strain UK1). Subsequent vaccination of hamsters with three doses of recombinant $\mathrm{CdeC}$ showed $100 \%$ survival of immunized hamsters after infection with C. difficile (strain 630) $[9,69]$.

The Role of Exosporium in the Infectious Process: The main object of research on the role of exosporium in the infectious process was the anthropozoonotic causative agent of anthrax, B. anthracis, which can form spores under aerobic conditions [13,84,89-94]. The initial stage of infection of the body largely occurs with the active participation of exosporium, namely, the interaction of its surface collagen glycoprotein BclA with the leukocyte integrin Mas-1 ( $\alpha \mathrm{M} \beta 2, \mathrm{CR} 3)$, which is an adhesion molecule $[26,60,110]$.

When pathogens spores enter the host organism, they are absorbed by macrophages and dendritic cells, which initiate clinical manifestations and the form of the disease (pulmonary, skin, or gastrointestinal) $[89,90,111-113]$. In any form of the disease, phagocytes migrate by the lymph, generating an infectious process. Spores germinate inside phagocytes and dendritic cells, multiply and produce toxins. In the lymph nodes, cells are lysed and vegetative forms of bacteria are released, followed by invasion of the bloodstream, active reproduction and the production of toxin, which mediates the clinical manifestations of the infection and leads to death. The stage of spore formation occurs only in the soil, under conditions of sufficient access of oxygen, which is an inducer of sporulation [100,114-116].

Thus, the key link in the infectious process is the binding of pathogen exospores to integrin and their phagocytosis. C. Oliva et al. and J. Bozue et al. showed that the exosporium of B. anthracis, devoid of BclA protein, does not bind to integrin [104]. It was shown that ramnose deoxysaccharide, which is part of BclA, binds to CD14 and acts as a co-receptor when interacting with integrin Mas-1, promoting phagocytosis $[78,79,110]$. The data presented indicate the leading role of the exosporium BclA glycoprotein in the pathogenesis of anthrax.
Despite the fact that in recent years' significant progress has been made in elucidating the structure and functions of exosporium, our understanding of the composition, mechanisms of its formation, and the role of this external structure of bacterial spores remains insufficient $[10,13,55,117]$. The use of modern analytical methods from the arsenal of the concept of molecular microbiology of single cells (atomic force microscopy, Raman spectroscopy, genetics) in the study of these structures is likely to become the key to a more complete understanding of the morphological, nanomechanical and biochemical characteristics of exospores $[15,117,118]$

\section{Modern Analytical Methods of Molecular Microbiology for Visualization and Study of Bacterial Spores}

Atomic Force Microscopy (AFM): from Imaging to Atomic Manipulation. Recently, one of the most dynamically developing and actively used in scientific research analytical technologies is scanning probe microscopy. One of its best-known tools is the atomic force microscope, invented in 1986 as a scanning tunnel profilometer [Binning, 1986]. Since the 90s of the last century, Atomic Force Microscopy (AFM) has become most actively used in biomedical research, thanks to a simple sample preparation procedure and the possibility of submicron visualization of biological objects [30,119-122].

For a short time, AFM as a method of three-dimensional visualization and research of local micromechanical properties has won leading positions in many fields of science, including microbiological studies, $[30,120,123]$. This analytical tool supplemented and expanded the capabilities of the main methods of visualization of microbiologists - light microscopy (goes beyond its technical resolution), as well as electron microscopy, the main drawback of which is the complexity of preparation of preparations and the need for research in high vacuum $[120,124,125]$.

The attractiveness of using AFM in microbiology is associated with some specific technical features of this diagnostic method, based not on the properties of the lenses, but on the use of a special probe (sensor) that analyzes the surface of the sample using a needle on a thin and flexible elastic cantilever installed in the holder (Figure 3). This visualization tool combines microscopy in the usual sense with nanomolecular detection of the mechanical, immunochemical, adhesive and electrostatic properties of an object (bacteria). These capabilities have made AFM an extremely useful and indispensable tool of molecular microbiology, and prokaryotic cells, due to their size and properties, have become a favorable object for research $[120,126,127]$. As a result of scanning, the AFM presents a digital three-dimensional topographic image of the surface of microorganisms in nanometer lateral and spatial resolution in any medium and at different temperatures [125,127].

In a short period of time, AFM has evolved from a topographic imaging method to an instrument for manipulating individual atoms and studying intermolecular interactions. 

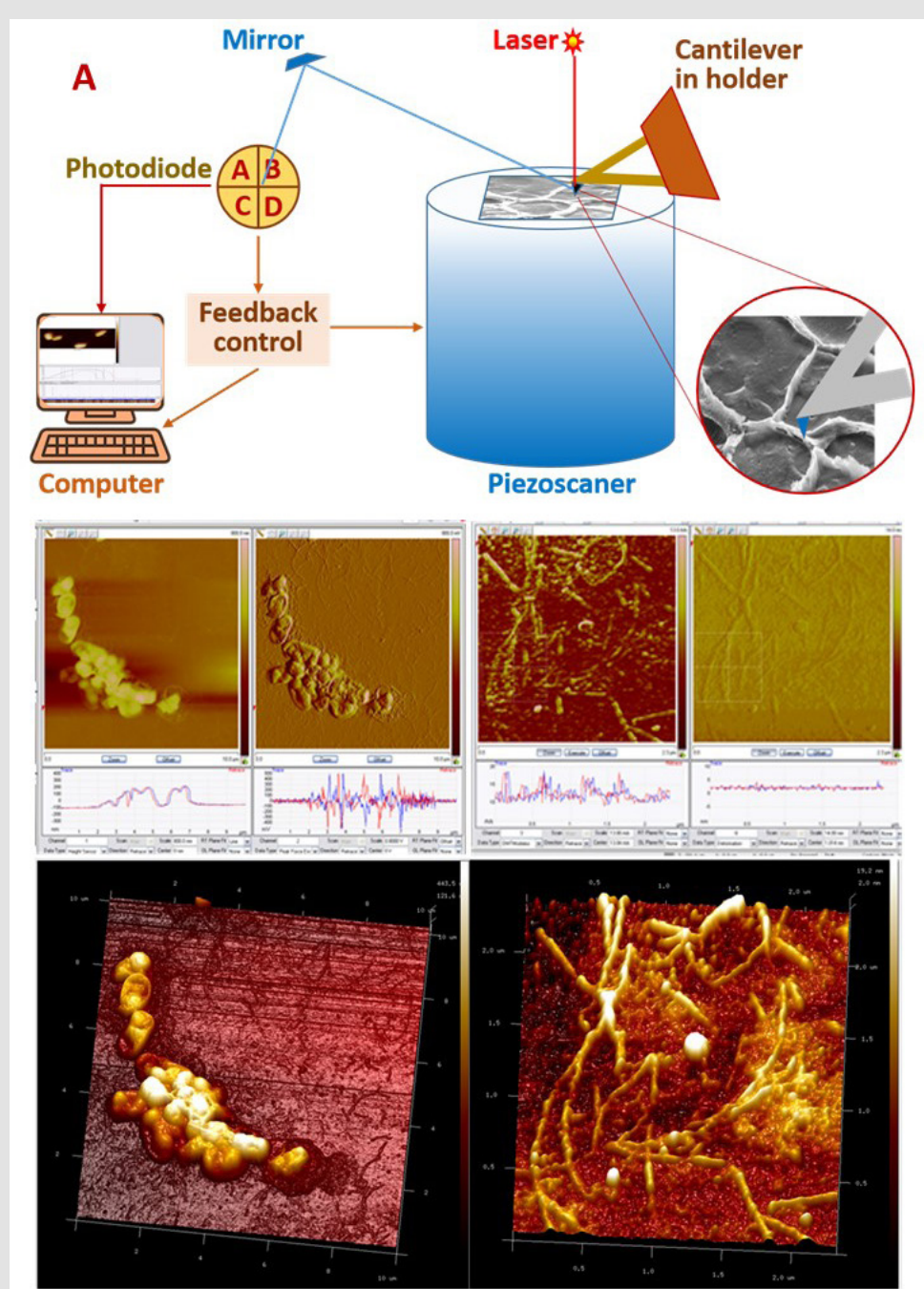

B

C

Figure 3: The AFM optical imaging system consists of a laser beam directed to the reflecting surface of the console and a 4 -section photodiode that fixes the vertical and lateral displacements of the probe (A). In the process of scanning the spores of B. subtilius after sporulation (B) and germination (C), the electronic system registers and the computer records the position of the probe at each point of the fixed surface of the object with coordinates $(X, Y, Z)$. A computer converts information from a piezoscanner into a 3-dimensional image (drawing and photo - authors).

\section{Consider the Possibilities of AFM in the Study of Bacterial Spores}

Periodic atomic-force observations of bacterial endospores make it possible to track the dynamic processes associated with sporulation or germination in vegetative cells. Essential for microbiological studies of bacteria spores is the possibility of use of AFM in several modes. In topographic mode ("constant effort"), the cantilever deviation is kept constant by using the feedback loop. In this case, the force of interaction of the needle with the surface of the sample strongly depends on the distance between them and is determined by adhesion, as well as by van der Waals and capillary interactions. The Z-position of the console reflects the topography (height) of the sample according to the type of geographic map, where the color of the image corresponds to the height of the relief $[120,122,127]$.
Being a method of force sensing, the AFM makes it possible to obtain not only an image of the surface topography and multilayer architecture of spores, but also their nanomechanical characteristics such as elasticity, viscosity, and adhesion [15,125127]. This practice makes it possible to simultaneously obtain information on the topography of the sample surface using Young's modulus (elastic modulus) and adhesion in the form of a highresolution image [119,122,128].

For example, studies by R. Giorno et al. [26,60] and V. Chada et al. [129], performed using AFM in aqueous solutions, are showed that the surface of spores of Bacillus spp. has a series of round ribbed nanometer protrusions on the outer shell, oriented along the longitudinal axis. R. Zolock and his colleagues showed that, based on these morphological features, four closely related species of Bacillus spores can be differentiated [130]. 
Visualization of spores in a fluid opens up wide prospects for monitoring dynamic processes, such as sporulation and germination of dormant cell forms. Interesting recent examples are studies of the dynamics of the germination of spores of Bacillus spp. in vegetative cells. After $30 \mathrm{~min}$ of incubation at room temperature, an increase (swelling) in the size of the spores was observed, and after 5-6 hours, all spores grew into vegetative cells, which immediately formed a biofilm [125,127].

A. Li et al. (2016) and T. Morisaku et al. [15,127] demonstrated the modern possibilities of using AFM in studying the nanomechanical properties of the internal structures of $B$. anthracis spores. Using a thermal probe AFM (Thermal Scanning Microscopy, SThM), they developed a method for nanosurgical cutting of spores using a hard diamond tip, and a soft probe was used to visualize and characterize its internal structures on a nanometer scale. It was found that the elasticity and adhesion indicators at elevated temperatures significantly varied in different areas of the spore cross section [127], and a previously unknown peptidoglycan ultrastructure of the $B$. anthracis spore cortex was found, consisting of rod-like structures of nanometer size oriented in the transverse direction relative to the longitudinal axis disputes $[15,118]$.

Over the nearly 30-year history of the use of atomic force microscopy in molecular microbiology, it has become a powerful research tool in the study of spores, effectively complementing light microscopy, genetics, and biochemical methods traditionally used to analyze the structure of bacterial spores. However, the potential use of this method in the study of bacterial dormant cell forms is sometimes underestimated and limited only by some of its functional capabilities [118,131]. Further use of AFM is associated with the use of dynamic (multi-frequency, multi-harmonic, bimodal) methods, which allow one to obtain faster, quantitative nanomechanical characteristics of a complex multilayer spore structure in higher resolution $[127,132]$.

In addition, it is interesting and promising to develop and use AFM biosensors for the quantitative visualization of individual molecules of structural proteins of endospores and exosporium using G-quadruplex DNA technologies or functionalized probes with individual chemical groups or single molecules immobilized on them, especially in combination with other analytical instruments, such as Raman spectroscopy [131-133].

\section{Raman Spectroscopy: New Possibilities of the Old Method}

The development of highly sensitive and rapid methods for the detection of bacterial spores is an urgent problem for medical diagnostics, epidemiology, and also solving biosafety problems. The public outcry caused by the bioterrorist attack in 2001, which used $B$. anthracis spores, exacerbated the problem of their timely detection and identification of pathogen. The material needed to be germinated in nutrient media to vegetative cell forms, biomass accumulation, and, finally, molecular genetic studies to identify the 16S rRNA gene specific for this type of pathogen. In addition, similar hours-long studies with other suspicious powders were required to determine the scale of the terror attack $[79,115,134]$.

As a result, awareness has come of the need to search for new informative and much faster detection methods of infectious agents. Early information on the identification of a pathogen could accelerate the onset of specific prophylaxis, etiopathogenetic treatment and minimize the tragic consequences of the attack associated with contamination and death of people $[29,135,136]$. The problem of quick identification is complicated by a number of aspects related to the minimum amount of test material - inhaling only $10^{4}$ endospores of $B$. anthracis (100 $\mathrm{ng}$ of powder) is a lethal dose for $50 \%$ of infected people. Moreover, it is necessary to differentiate a pathogenic material from a similar but harmless to eliminate of panic fear that accompanies epidemic outbreaks of dangerous infections $[99,115,137]$.

Therefore, the new method of indication should be not only fast, but also highly specific, reliably differentiate dangerous bacterial endospores from other biological objects, in any environmental objects. Raman spectroscopy (RS) - a method known for more than 80 years and has long been widely used as an analytical and applied tool in the chemical and technical fields, meets these criteria $[53,86,121]$

The low intensity of the signal received from living objects has long served as an obstacle to the use of MS in biomedical research. However, after the appearance of several improvements in this technology in the last 10-20 years (first of all, combining RS with a confocal microscope, as well as various ways of amplifying the Raman signal), the method began to be widely used in biomedical research without spending time on the stages of sample preparation and special labeling or staining [121]. In particular, this powerful analytical tool in recent years has been actively used for quick, inexpensive, and effective solution of the problems of molecular microbiology [53] (Figure 4).

The attractiveness of RS is associated with non-invasiveness (the ability to study bacteria without destroying them), minimal sample preparation, the absence of the need for tags and probes, and the speed of obtaining the result. The test sample is placed in the focus of the excitation laser and measured. Molecular information obtained with the help of RS makes it possible to uniquely identify a microorganism by the specific spectrum of its chemical and biochemical substances $[115,135,136]$. In addition, the possibility of obtaining data on the molecular structure of bacterial cells located in different phases of the life cycle, as well as studying the dynamics of some cellular processes, made this method a powerful analytical tool for the study of spores. 


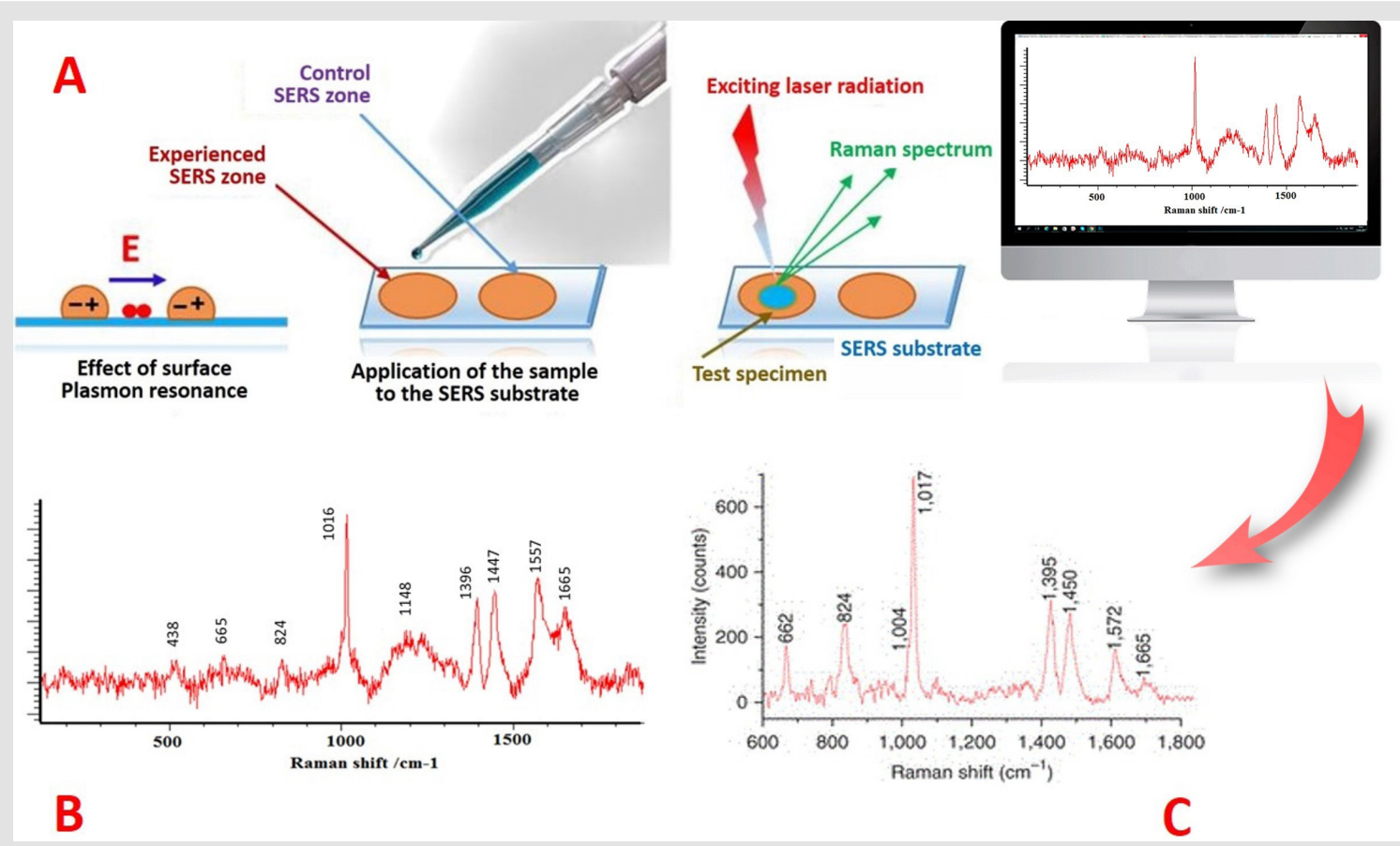

Figure 4: For the registration of spectra, the possibility of amplifying the signal of Raman scattering due to the excitation of surface plasmons is important. The use of silver or gold nanoparticles as a SERS substrate increases the received signal $10^{6}$ times (A). Such gigantic amplification made Raman signals more intense and stable than the fluorescence of molecules. Raman spectra of B. Subtilius spores (B) and B. cereus (C). Illustrations by the authors.

\section{Possibilities of RS in the Study of Bacterial Spores}

Significant differences in the Raman spectra of vegetative and spore cell forms of bacteria were discovered long ago in the study of Bacillus spp. These differences are associated with the predominance in the resonance spectra of bacterial endospores of Calcium Dipicolinate (Ca-DPA), the major peaks of which were detected at vibrational frequencies of 1015-1017 $\left(\mathrm{cm}^{-1}\right)$ at an excitation wavelength of $244 \mathrm{~nm}[19,42,43,48,137]$.

As indicated above, the content of this biomarker is up to $15 \%$ of the dry weight of spores and its content varies depending on the species, strain of spore-forming bacteria and sporulation conditions $[38,39,42,48]$. The obtained Raman spectra of B. cereus, $B$. anthracis, and B. subtilis spores turned out to be very similar, and Ca-DPA was proposed as a sensitive biomarker for the rapid detection of Bacillus spp spores. [138-140]. So, S. Wang et al. (2015 and 2016) studied the kinetics and levels of berberine alkaloid accumulation in spores of Bacillus spp and Clostridium spp. and its effect on their germination. The aim of the study was to find means of minimizing the potential danger of germinated spores and ways to destroy them after or during germination. In this study, laser tweezers RS in combination with fluorescence and differential interference microscopy were used to analyze the localization, level and kinetics of absorption of berberine in a separate resting and germinating spore [1,141].

The combination of AFM and RS methods is a very promising analytical tool for the study of bacterial spores. Such integrated diagnostic systems have been used in molecular microbiology in recent years $[121,49]$. Information on the structural topographic and nanomechanical properties is supplemented by data on the submicron molecular profile, which gives a fairly complete picture and a better understanding of dormant systems [121]. For example, a study by R. Boitor at al. (2015) quantified RNA, DNA, and proteins of bacterial cell forms by recording Raman spectra and calibration models for each structural component and adjusting focal effects using an AFM topographic image [142].

In recent years, when studying bacterial spores, spectroscopic methods have especially attracted attention as the main element for combination with other analytical tools [53,121,143]. Such an interdisciplinary approach reflects a new modern trend and is an indispensable research technology for multi-parameter studies of the heterogeneity of single cells in microbiology (the concept of Single Cell Microbiology), including bacterial spores. And in this sense, AFM and RS are examples of new analytical tools and methods that provide a unique opportunity to observe discrete microbiological phenomena that are inaccessible when using traditional approaches.

\section{Bacterial Spores as an Object of Modern Plasma- Chemical Biotechnologies}

Bacterial spores have been known since the advent of microbiology as a science. For many years they have been examined from the point of view of epidemiological and pathogenetic importance for the occurrence of infections. As mentioned above, extreme resilience in the environment has made bacterial spores a serious public health problem. Existing sterilization methods (dry 
and wet steam, chlorine-containing substances, $\gamma$-radiation and others) are not effective enough, especially when decontamination of surgical instruments, medical equipment or drugs. Therefore, the search for means and methods for the destruction of bacterial spores has been and remains an urgent scientific task, many multidisciplinary studies are aimed at solving it.

To this end, recently, the possibility of using non-thermal (cold) plasma, which has an ambient temperature, which can be used to process thermosensitive objects and is considered as a potential alternative to traditional sterilization methods [143-146].

Such plasma is generated by the action on a gas (for example, any of the inert ones) of electric or electromagnetic fields. The field energy causes the acceleration of free electrons and ionizes the atoms and molecules of the gas. Excited atoms and molecules, returning to a more stable state, emit excess energy in the form of electromagnetic and ultraviolet radiation, as well as generated active forms of oxygen and nitrogen with wide, including powerful antimicrobial, action spectra [147-149]. The most studied applications of this technology in the field of biology and medicine are sterilization of products, decontamination of medical equipment, surgical implants, and treatment of wound surfaces $[148,150,151]$. Fast (seconds-minutes) and effective cold plasma inactivation of dormant and vegetative cell forms of pathogenic gram-negative and gram-positive bacteria, including Bacillus spp spores. and Clostridium spp., aroused considerable interest of microbiologists [152-154]. It is focused primarily on the study and characterization of the antimicrobial efficacy of plasma, as well as the mechanisms of microbial inactivation and sporocidal action, which are currently being actively studied $[147,155,156]$.

\section{Conclusion and Prospects}

Bacterial spores are unique and extremely inert biological systems, the mechanisms of which are opposed to extreme conditions are not fully understood. Understanding the mechanisms of resistance of these dormant forms is of great biomedical importance and can potentially lead to new methods of prevention and sterilization, which will be aimed at vulnerable structures of endo- and exospores. The long history of the study of endospores allowed us to make a detailed analysis and description of the sporulation and germination process in selected model microorganisms, to create a solid foundation for understanding the cellular processes leading to the formation of these dormant forms, partly to learn the diverse mechanisms of their stability. The result of these studies was the conceptual belief that the high resistance of bacterial spores can be of value and direct application in various fields of biotechnology.

Currently, their research continues at a new, nanostructured level. In particular, bacterial spores are of scientific interest as a biological model for studying the mechanisms of formation of complex supramolecular structures and are becoming a target for modern biotechnology on the principle of "learn from nature" [157-159]. For example, the development of using models of the natural architectonics of endospores to create self-organizing supramolecular structures used as nanosized substrates for packaging and targeted delivery of enzymes, nucleic acids, antigens, and drugs to certain tissues, cells, and even intracellular organelles is very promising [160-162]. These surfaces can be used as biocoatings or molecular switches driven by chemicals, electrons, or light $[163,164]$.

The direct use of endospores is also considered, but there is a significant risk associated with the germination and vegetative growth of bacteria before reaching the target tissue. Nevertheless N.G. Roberts and colleagues (2014) used the endospores of $C$. histolyticum and C. novyi in an experiment. The researchers found that during germination and vegetative growth, these species caused tumor cell lysis or tumor regression $[158,165]$.

Another area associated with the use of spores in the treatment of cancerous tumors is the selective expression of specific enzymes with the predominant germination of dormants in hypoxic tumors [162]. Since the beginning of the $21^{\text {st }}$ century, studies have been conducted on the use of recombinant bacterial spores to create thermostable vaccines $[157,158,165]$. In 2007, N.Q. Uyen et al. [160] conducted a successful experiment in protecting mice against tetanus by oral or nasal administration of vaccines designed based on the $C$. tetani TTFC antigen on the surface of $B$. subtilis spores. The prospects of these biotechnologies are evidenced by pilot studies $[163,164]$. Recent publications $[10,37,159]$ have suggested that spores and spore-forming bacteria can play an important role in the development and spread of antibiotic resistance due to their biological properties, their ability to disperse, and thereby the spread of antimicrobial resistance genes. substances in a state of metabolic rest $[10,37,159]$.

The unique properties of bacterial spores are likely to find application in other ecosystem technologies in the near future, for example, in paleoecological soundings, as biofungicides and bioinsecticides in agriculture, as well as bioremediation and biomineralization (biologically induced and controlled mineralization processes that occur in nature).

\section{Reference}

1. Wang S, Shen A, Setlow P, Li YQ (2015) Characterization of the dynamic germination of individual Clostridium difficile spores using raman spectroscopy and differential interference contrast microscopy. J Bacteriol 197(14): 2361-2373.

2. Mendoza RS, Angulo C, Meza B (2016) Food-Grade organisms as vaccine biofactories and oral delivery vehicles. Trends in Biotechnology 34: 124136.

3. Carrasco BJ, Sabja PD (2014) Clostridium difficile spores: A major threat to the hospital environment. Future Microbiology 9: 475-486.

4. Abhyankar W, Pandey R, Beek TA, Brul S, Koning LJ D, et al. (2015) Reinforcement of Bacillus subtilis spores by cross-linking of outer coat proteins during maturation. Food Microbiol 45: 54-62.

5. Isoard BC, Broussolle V, Carlin F (2018) Sporulation environment influences spore properties in Bacillus: Evidence and insights on underlying molecular and physiological mechanisms. FEMS Microbiol Rev 42(5): 614-626. 
6. Nicholson WL (2002) Roles of bacillus endospores in the environment Cell Mol Life Sci 59: 410-416.

7. Sabja PD, Shen A, Sorg JA (2014) Clostridium difficile spore biology: Sporulation, germination, and spore structural proteins. Trends Microbiol 22: 406-416

8. Rupnik M, Wilcox MH, Gerding DN (2009) Clostridium difficile infection: New developments in epidemiology and pathogenesis. Nat Rev Microbiol 7: 526-536.

9. Guajardo PM, Veloso CN, Vidal RM, Sabja PD (2019) New insights for vaccine development against Clostridium difficile infections. Anaerobe 58: 73-79.

10. Romero CP, Cordova CP, Ramirez RR, Cespedes MM, Araya GE, et al. (2018) Clostridium difficile exosporium cysteine-rich proteins are essential for the morphogenesis of the exosporium layer, spore resistance, and affect C. difficile pathogenesis. PLoS Pathog 14: e1007199.

11. McDonald LC, Gerding DN, Johnson S, Bakken JS, Carroll KC, et al. (2018) Clinical practice guidelines for Clostridium difficile infection in adults and children: 2017 Update by the Infectious Diseases Society of America (IDSA) and Society for Healthcare Epidemiology of America (SHEA). Clin Infect Dis 66(7): e1-e48.

12. Janganan TK, Mullin N, Tzokov SB, Stringer S, Fagan RP, et al. (2016) Characterization of the spore surface and exosporium proteins of clostridium sporogenes; Implications for Clostridium botulinum group strains. Food Microbiol 59: 205-212.

13. Stewart GC (2015) The exosporium layer of bacterial spores: A connection to the environment and the infected host. Microbiol Mol Biol Rev 79(4): 437-457.

14. Isoard BC, Bornard I, Henriques AO, Carlin F, Broussolle V (2016) Sporulation temperature reveals a requirement for CotE in the assembly of both the coat and exosporium layers of Bacillus cereus spores. Appl Environ Microbiol 82: 232-243.

15. Li AG, Burggraf LW, Xing Y (2016) Nanomechanical characterization of Bacillus anthracis spores by atomic force microscopy. Appl Environ Microbiol 82(10): 2988-2999.

16. Fritze D (2004) Taxonomy of the genus bacillus and related genera: The aerobic endospore-forming bacteria. Phytopathology 94: 1245-1248.

17. Kailas L, Terry C, Abbott N, Taylor R, Mullin N, et al. (2011) Surface architecture of endospores of the Bacillus cereus/anthracis/thuringiensis family at the subnanometer scale. Proc Natl Acad Sci USA 108: 16014 16019.

18. Terry C, Shepherd A, Radford DS, Moir A, Bullough PA (2011) YwdL in Bacillus cereus: Its role in germination and exosporium structure. PLoS One 6: e23801.

19. Cetinkaya Y, Yurt MN Z, Oktem AH, Yilmaz MD (2019) A monostyryl boradiazaindacene (BODIPY)-based lanthanide-free colorimetric and fluorogenic probe for sequential sensing of copper (II) ions and dipicolinic acid as a biomarker of bacterial endospores. J Hazard Mater 377: 299-304.

20. Manetsberger J, Ghosh A, Hall EA H, Christie G (2018) Orthologues of Bacillus subtilis spore crust proteins have a structural role in the Bacillus megaterium QM B1551 spore exosporium. Appl Environ Microbiol 84(20): e01734-e01718.

21. Tan IS, Ramamurthi KS (2014) Spore formation in Bacillus subtilis Environ Microbiol Rep 6: 212-225.

22. Russell JR, Cabeen MT, Wiggins PA, Paulsson J, Losick R (2017) Noise in a phosphorelay drives stochastic entry into sporulation in Bacillus subtilis. EMBO J 36(19): 2856-2869.

23. Steichen C, Kearney JF, Turnbough CL (2007) Non-uniform assembly of the Bacillus anthracis exosporium and a bottle cap model for spore germination and outgrowth. Mol Microbiol 64: 359-367.

24. Thompson BM, Waller LN, Fox KF, Fox A, Stewart GC (2007) The BclB glycoprotein of Bacillus anthracis is involved in exosporium integrity. J Bacteriol 189: 6704-6713.
25. Errington J (2003) Regulation of endospore formation in Bacillus subtilis. Nat Rev Microbiol 1: 117-126.

26. Giorno R, Bozue J, Cote C, Wenzel T, Moody KS, etal. (2007) Morphogenesis of the Bacillus anthracis spore. J Bacteriol 189: 691-705.

27. Mckenney PT, Driks A, Eichenberger P (2013) The Bacillus subtilis endospore: Assembly and functions of the multilayered coat. Nat Rev Micro 11: 33-44.

28. Jiang S, Wan Q Krajcikova D, Tang J, Tzokov SB, et al. (2015) Diverse supramolecular structures formed by self-assembling proteins of the Bacillus subtilis spore coat. Mol Microbiol 97: 347-359.

29. Brunsing RL, La Clair C, Tang S, Chiang C, Hancock LE, et al. (2005) Characterization of sporulation histidine kinases of Bacillus anthracis. J Bacteriol 187: 6972-6981.

30. Pratda VG, Sanstad EA, Wang R, Driks A (2003) Morphogenesis of Bacillus spore surfaces. J Bacteriol 185: 6255-6261.

31. Setlow P (2006) Spores of Bacillus subtilis: their resistance to and killing by radiation, heat and chemicals. J Appl Microbiol 101(3): 514-525.

32. Hong HA, Hitri K, Hosseini S, Kotowicz N, Bryan D, et al. (2017) Mucosal antibodies to the $\mathrm{C}$ terminus of toxin a prevent colonization of Clostridium difficile. Infect Immun 85(6): e00279-e00217.

33. Widderich N, Rodrigues CD A, Commichau FM, Fischer KE, RamirezGuadiana FH, et al. (2016) Salt-sensitivity of sigma(H) and Spo0A prevents sporulation of Bacillus subtilis at high osmolarity avoiding death during cellular differentiation. Molecular Microbiology 100: 108124.

34. Logan NA (2012) Bacillus and relatives in foodborne illness. J Appl Microbiol 112: 417-429.

35. Bailey-Smith K, Todd SJ, Southworth TW, Proctor J, Moir A (2005) The ExsA protein of Bacillus cereus is required for assembly of coat and exosporium onto the spore surface. J Bacteriol 187: 3800-3806.

36. Hosoya S, Lu Z, Ozaki Y, Takeuchi M, Sato T (2007) Cytological analysis of the mother cell death process during sporulation in Bacillus subtilis. J Bacteriol 189: 2561-2565.

37. Setlow P (2014) Spore resistance properties. Microbiol Spectrum 2: 1-14.

38. Batalha IL, Ke P, Tejeda-Montes E, Uddin S, van der Walle CF, (2017) Dipicolinic acid as a novel spore-inspired excipient for antibody formulation. Int J Pharm 526(1-2): 332-338.

39. Cheung M, Lee WW, Cowcher DP, Goodacre R, Bell SE (2016) SERS of meso-droplets supported on superhydrophobic wires allows exquisitely sensitive detection of dipicolinic acid, an anthrax biomarker, considerably below the infective dose. Chem Commun (Camb) 52(64): 9925-9928.

40. Scheldeman P, Herman L, Foster S, Heyndrickx M (2006) Bacillus sporothermodurans and other highly heatresistant spore formers in milk. J Appl Microbiol 101: 542-555.

41. Schubert WW, Beaudet RA (2011) Determination of lethality rate constants and D-values for heat-resistant Bacillus spores ATCC 29669 exposed to dry heat from $125^{\circ} \mathrm{C}$ to $200^{\circ} \mathrm{C}$. Astrobiology 11 : 1-11.

42. Pestov D, Zhi M, Sariyanni ZE, Kalugin NG, Kolomenskii AA, et al. (2005) Visible and UV coherent Raman spectroscopy of dipicolinic acid. Proc Natl Acad Sci U S A 102(42): 14976-4981.

43. Sliemandagger TA, Nicholson WL (2001) Role of dipicolinic acid in survival of Bacillus subtilis spores exposed to artificial and solar UV radiation. Appl Environ Microbiol 67(3): 1274-1279.

44. Di Filippo P, Pomata D, Riccardi C, Buiarelli F, Uccelletti D, et al. (2017) Muramic and dipicolinic acids in atmospheric particulate matter as biomarkers of bacteria and bacterial spores. Anal Bioanal Chem 409(6): 1657-1666.

45. Setlow P (2007) I will survive: DNA protection in bacterial spores. Trends Microbiol 15: 172-180. 
46. Driks A (2003) The dynamic spore. Proc Natl Acad Sci USA 100: 3007 3009.

47. Wang C, Ehrhardt CJ, Yadavalli VK (2015) Single cell profiling of surface carbohydrates on Bacillus cereus. J R Soc Interface 12(103): 20141109.

48. Bai XR, Zeng Y, Zhou XD, Wang XH, Shen AG, et al. (2017) Environmentally safe mercury (II) ions aided zero-background and ultrasensitive SERS detection of dipicolinic acid. Anal Chem 89(19):10335-10342.

49. Gao L, Zhao H, Li T, Huo P, Chen D, Liu B (2018) Atomic force microscopy based tip-enhanced raman spectroscopy in biology. Int J Mol Sci 19(4). E1193.

50. Wrobel TP, Bhargava R (2018) Infrared spectroscopic imaging advances as an analytical technology for biomedical sciences. Anal Chem 90(3): 1444-1463.

51. Westphal AJ, Price PB., Leighton TJ, Wheeler KE (2003) Kinetics of size changes of individual Bacillus thuringiensis spores in response to changes in relative humidity. Proc Natl Acad Sci USA 100: 3461-3466.

52. Higgins D, Dworkin J (2012) Recent progress in Bacillus subtilis sporulation. FEMS Microbiol Rev 36: 131-148.

53. Kong M, Na H, Nam-Chul Ha, Ryu S (2019) LysPBC2, a novel endolysin harboring a Bacillus cereus spore binding domain. Appl Environ Microbiol 85(5): e02462-e02418.

54. Lequette Y, Garénaux E, Combrouse T, Del Lima Dias T, Ronse A, et al. (2011) Domains of BclA, the major surface glycoprotein of the B. cereus exosporium: Glycosylation patterns and role in spore surface properties Biofouling 27: 751-761.

55. Manetsberger J, Hall EA H, Christie G (2015) Plasmid-encoded genes influence exosporium assembly and morphology in Bacillus megaterium QM B1551 spores. FEMS Microbiol 362: 147.

56. Abhyankar WR, Kamphorst K, Swarge BN, Van Veen H, Van der Wel NN, et al. (2016) The influence of sporulation conditions on the spore coat protein composition of Bacillus subtilis spores. Front Microbiol 7: 1-10.

57. Checinska A, Paszczynski A, Burbank M (2015) Bacillus and other sporeforming genera: Variations in responses and mechanisms for survival. Annu Rev Food Sci Technol 6: 351-369.

58. Ireland JA, Hanna PC (2002) Amino acid- and purine ribonucleosideinduced germination of Bacillus anthracis DSterne endospores: GerS mediates responses to aromatic ring structures. J Bacteriol 184: 12961303.

59. Cybulski, Sanz RJ, McDaniel D, Darnell S, Bull RL, et al. (2008) Recombinant Bacillus anthracis spore proteins enhance protection of mice primed with suboptimal amounts of protective antigen. Vaccine 26: 4927-4939.

60. Giorno R, Bozue J, Mallozzi M, Moody KS, Slack A, et al. (2009) Characterization of a Bacillus anthracis spore protein with roles in exosporium morphology. Microbiology 155: 1133-1145.

61. Ramirez-Peralta A, Zhang PF, Li YQ, Setlow P (2012) Effects of sporulation conditions on the germination and germination protein levels of Bacillus subtilis spores. Appl Environ Microbiol 78: 2689-2697.

62. Imamura D, Kuwana R, Takamatsu H, Watabe K (2011) Proteins involved in formation of the outermost layer of Bacillus subtilis spores. J Bacteriol 193: $4075-4080$

63. Terry C, Jiang S, Radford DS, Wan Q Tzokov S, et al. (2017) Molecular tiling on the surface of a bacterial spore - the exosporium of the Bacillus anthracis/cereus/thuringiensis group. Mol Microbiol 104(4): 539-552.

64. Barra-Carrasco J, Olguin-Araneda V, Plaza-Garrido A, Miranda-Cardenas C, Cofre-Araneda G, et al. (2013) The Clostridium Difficile Exosporium Cysteine (CdeC)-rich protein is required for exosporium morphogenesis and coat assembly. J Bacteriol 195: 3863-3875.

65. Diaz-Gonzalez F, Milano M, Olguin-Araneda V, Pizarro-Cerda J, Castro-Cordova P, et al. (2015) Protein composition of the outermost exosporium-like layer of Clostridium difficile 630 spores. J Proteomics 123: 1-13.
66. McPherson SA, Li M, Kearney JF, Turnbough CL (2010) ExsB, an unusually highly phosphorylated protein required for the stable attachment of the exosporium of Bacillus anthracis. Mol Microbiol 76:1527-1538.

67. Rodenburg CM, McPherson SA, Turnbough CL, Dokland T (2014) Cryo$\mathrm{EM}$ analysis of the organization of $\mathrm{BclA}$ and $\mathrm{BxpB}$ in the Bacillus anthracis exosporium. J Struct Biol 186: 181-187.

68. Ehling-Schulz M, Lereclus D, Koehler TM (2019) The Bacillus cereus group: Bacillus species with pathogenic potential. Microbiol Spectr 7(3).

69. Pizarro-Guajardo M, Calderon-Romero P, Castro-Cordova P, Mora-Uribe P, Paredes-Sabja D (2016) Ultrastructural variability of the exosporium layer of Clostridium difficile spores. Appl Environ Microbiol 82: 2202 2209.

70. Pizarro-Guajardo M, Diaz-Gonzalez F, Alvarez-Lobos M, Paredes-Sabja D (2017) Characterization of chicken IgY specific to Clostridium difficile R20291 spores and the effect of oral administration in mouse models of initiation and recurrent disease. Front Cell Infect Microbio 1 7: 365.

71. Pizarro-Guajardo M, Olguin-Araneda V, Barra-Carrasco J, Brito-Silva C, Sarker MR, et al. (2014) Characterization of the collagen-like exosporium 634 protein, BclA1, of Clostridium difficile spores. Anaerobe 25: 18-30.

72. Pizarro-Guajardo M, Ravanal MC, Paez MD, Callegari E, Paredes-Sabja D (2018) Identification of Clostridium difficile immunoreactive spore proteins of the epidemic strain R20291. Proteomics Clin Appl 12(5): e1700182.

73. Mora-Uribe P, Miranda-Cardenas C, Castro-Cordova P, Gil F, Calderon I, et al. (2016) Characterization of the adherence of Clostridium difficile spores: The integrity of the outermost layer affects adherence properties of spores of the epidemic strain r20291 to components of the intestinal mucosa. Front Cell Infect Microbiol 6: 99.

74. Boydston JA, Yue L, Kearney JF, Turnbough CL (2006) The ExsY protein is required for complete formation of the exosporium of Bacillus anthracis. J Bacteriol 188: 7440-7448.

75. Boydston JA, Chen P, Steichen CT, Turnbough CL (2005) Orientation within the exosporium and structural stability of the collagen-like glycoprotein BclA of Bacillus anthracis. J Bacteriol 187: 5310-5317.

76. Brahmbhatt TN, Janes BK, Stibitz ES, Darnell SC, Sanz P, et al. (2007) Bacillus anthracis exosporium protein BclA affects spore germination, interaction with extracellular matrix proteins, and hydrophobicity. Infect Immun 75: 5233-5239.

77. Brahmbhatt TN, Darnell SC, Carvalho HM, Sanz P, Kang TJ, et al. (2007) Recombinant exosporium protein BclA of Bacillus anthracis is effective as a booster for mice primed with suboptimal amounts of protective antigen. Infect Immun 75: 5240-5247.

78. Bozue JA, Welkos S, Cote CK (2015) The Bacillus anthracis exosporium: What's the Big "Hairy" Deal? Microbiol Spectr 3(5).

79. Bozue JA, Cote CK, Moody KL, Welkos SL (2007) Fully virulent Bacillus anthracis does not require the immunodominant protein $\mathrm{BclA}$ for pathogenesis. Infect Immun 75: 508-511.

80. Ball DA, Taylor R, Todd SJ, Redmond C, Couture-Tosi E, et al. (2008) Structure of the exosporium and sublayers of spores of the Bacillus cereus family revealed by electron crystallography. Mol Microbiol 68: 947-958.

81. Sylvestre P, Couture Tosi E, Mock M (2003) Polymorphism in the collagen-like region of the Bacillus anthracis BclA protein leads to variation in exosporium filament length. J Bacteriol 185: 1555-1563.

82. Sylvestre P, Couture-Tosi E, Mock M (2005) Contribution of ExsFA and ExsFB proteins to the localization of BclA on the spore surface and to the stability of the Bacillus anthracis exosporium. J Bacteriol 187: 5122 5128.

83. Wang C, Stanciu C, Ehrhardt CJ, Yadavalli VK (2015) Morphological and mechanical imaging of Bacillus cereus spore formation at the nanoscale. J Microscopy 258(1): 49-58.

84. Weaver J, Kang TJ, Raines KW, Cao GL, Hibbs S, et al. (2007) Protective -role of Bacillus anthracis exosporium in macrophage-mediated killing by nitric oxide. Infect Immun 75: 3894-3901. 
85. Todd SJ, Moir AJ G, Johnson MJ, Moir A (2003) Genes of Bacillus cereus and Bacillus anthracis encoding proteins of the exosporium. J Bacteriol 185: 3373-3378.

86. Wang Y, Jenkins SA, Gu C, Shree A, Martinez-Moczygemba M, et al. (2016) Bacillus anthracis spore surface protein BclA mediates complement factor $\mathrm{H}$ binding to spores and promotes spore persistence. PLoS Pathog 12: e1005678.

87. Mehta AS, Saile E, Zhong W, Buskas T, Carlson R, et al. (2006) Synthesis and antigenic analysis of the BclA glycoprotein oligosaccharide from the Bacillus anthracis exosporium. Chemistry 12: 9136-9149.

88. Johnson MJ, Todd SJ, Ball DA, Shepherd AM, Sylvestre P, et al. (2006) ExsY and CotY are required for the correct assembly of the exosporium and spore coat of Bacillus cereus. J Bacteriol 188: 7905-7913.

89. Thompson BM, Stewart GC (2008) Targeting of the BclA and BclB proteins to the Bacillus anthracis spore surface. Mol Microbiol 70: 421434.

90. Thompson BM, Hsieh HY, Spreng KA, Stewart GC (2011) The codependence of BxpB/ExsFA and BclA for proper incorporation into the exosporium of Bacillus anthracis. Mol Microbiol 79: 799-813.

91. Thompson BM, Hoelscher BC, Driks A, Stewart GC (2012) Assembly of the BclB glycoprotein into the exosporium and evidence for its role in the formation of the exosporium "cap" structure in Bacillus anthracis. Mol Microbiol 86: 1073-1084.

92. Steichen C, Kearney JF, Turnbough CL (2005) Characterization of the exosporium basal layer protein BxpB of Bacillus anthracis. J Bacteriol 187: $5868-5876$

93. Severson KM, Mallozzi M, Bozue J, Welkos SL, Cote CK, et al. (2009) Roles of the Bacillus anthracis spore protein ExsK in exosporium maturation and germination. J Bacteriol 191: 7587-7596.

94. Boone TJ, Mallozzi M, Nelson A, Thompson B, Khemmani M, et al. (2018) Coordinated assembly of the Bacillus anthracis coat and exosporium during bacterial spore outer layer formation. MBio 9(6): e01166-e01118.

95. Lanzilli M, Donadio G, Addevico R, Saggese A, Cangiano G, et al. (2016) The exosporium of Bacillus megaterium QM B1551 is permeable to the red fluorescence protein of the coral Discosoma sp. Front Microbiol 7 1752 .

96. McKenney PT, Driks A, Eskandarian HA, Grabowski P, Guberman J, et al. (2010) A distance-weighted interaction map reveals a previously uncharacterized layer of the Bacillus subtilis spore coat. Curr Biol 20: 934-938.

97. Shuster B, Khemmani M, Abe K, Huang X, Nakaya Y, et al. (2019) Contributions of crust proteins to spore surface properties in Bacillus subtilis. Mol Microbiol 111(3): 825-843.

98. Yan X, Gai Y, Liang L, Liu G, Tan H (2007) A gene encoding alanine racemase is involved in spore germination in Bacillus thuringiensis. Arch Microbiol 187: 371-378.

99. Chesnokova ON, McPherson SA, Steichen CT, Turnbough CL (2009) The spore-specific alanine racemase of Bacillus anthracis and its role in suppressing germination during spore development. J Bacteriol 191: 1303-1310.

100. Driks A (2009) The Bacillus anthracis spore. Mol Aspects Med 30(6): 368-373.

101. Horii T, Notake S, Tamai K, Yanagisawa H (2011) Bacillus cereus from blood cultures: Virulence genes, antimicrobial susceptibility and risk factors for blood stream infection. FEMS Immunol Med Microbiol 63 202-209.

102. Gauthier YP, Tournier JN, Paucod JC, Corre JP, Mock M, et al. (2009) Efficacy of a vaccine based on protective antigen and killed spores against experimental inhalational anthrax. Infect Immun 77: 11971207.

103. Ghose C, Eugenis I, Edwards AN, Sun X, McBride SM, et al. (2016) Immunogenicity and protective efficacy of Clostridium difficile spore proteins. Anaerobe 37: 85-95.
104. Vedantam G, Kochanowsky J, Lindsey J, Mallozzi M, Roxas JL, et al. (2018) An engineered synthetic biologic protects against Clostridium difficile infection. Front Microbiol 9: 2080.

105. Driks A, Eichenberger P (2016) The spore coat. Microbiol Spectr 4: $1-22$.

106. Sorg JA, Sonenshein AL (2008) Bile salts and glycine as cogerminants for Clostridium difficile spores. J Bacteriol 190: 2505-2512.

107. Dubberke ER, Olsen MA (2012) Burden of Clostridium difficile on the healthcare system. Clin Infect Dis 55: S88-S92.

108. Driks A (2007) Surface appendages of bacterial spores. Mol Microbiol 63: 623-625.

109. Edwards AN, McBride SM (2014) Initiation of sporulation in Clostridium difficile: A twist on the classic model. FEMS Microbiol Lett 358: 110-118.

110. Oliva CR, Swiecki MK, Griguer CE, Lisanby MW, Bullard DC, et al. (2008) The integrin Mac-1 (CR3) mediates internalization and directs Bacillus anthracis spores into professional phagocytes. Proc Natl Acad. Sci USA 105: 1261-1266.

111. Driks A (2009) The Bacillus anthracis spore. Mol Aspects Med 30(6): 368-373.

112. Tournier JN, Ulrich RG, Hellmann QA, Mohamadzadeh M, Stiles BG (2009) Anthrax, toxins and vaccines: A 125-year journey targeting Bacillus anthracis. Expert Rev Anti Infect Ther 7: 219-236.

113. Perego M, Hoch JA (2008) Commingling regulatory systems following acquisition of virulence plasmids by Bacillus anthracis. Trends Microbiol 16: 215-221.

114. Liu S, Moayeri M, Leppla SH (2014) Anthrax lethal and edema toxins in anthrax pathogenesis. Trends Microbiol 22: 317-325.

115. Fisher N, Hanna P (2005) Characterization of Bacillus anthracis germinant receptors in vitro. J Bacteriol 187: 8055-8062.

116. McKevitt MT, Bryant KM, Shakir SM, Larabee JL, Blanke SR, et al. (2007) Effects of endogenous D-alanine synthesis and autoinhibition of Bacillus anthracis germination on in vitro and in vivo infections. Infect Immun 75: 5726-5734.

117. Basoli F, Giannitelli SM, Gori M, Mozetic P, Bonfanti A, et al. (2018) Biomechanical characterization at the cell scale: Present and Prospects. Front Physiol 9: 1449 .

118. Yoo L, Reed J, Shin A, Demer JL (2014) Atomic force microscopy determination of young's modulus of bovine extra-ocular tendon fiber bundles. J Biomech 47(8): 1899-1903.

119. Alsteens D, Müller DJ, Dufrêne YF (2017) Multiparametric atomic force microscopy imaging of biomolecular and cellular systems. Acc Chem Res 50(4): 924-931.

120. Bolshakova AV, Kiselyova OI, Yaminsky IV (2004) Microbial surfaces investigated using atomic force microscopy. Biotechnol Prog 20: 16151622.

121. Prats-Mateu B, Gierlinger N (2017) Tip in-light on: Advantages, challenges, and applications of combining AFM and Raman microscopy on biological samples. Microsc Res Tech 80(1): 30-40.

122. Gavara N (2017) A beginner's guide to atomic force microscopy probing for cell mechanics. Microsc Res Tech 80(1): 75-84.

123. Scheuring S, Dufrêne YF (2010) Atomic force microscopy: probing the spatial organization, interactions and elasticity of microbial cell envelopes at molecular resolution. Mol Microbiol 75(6): 1327-1336.

124. Muller DJ, Dufrêne YF (2008) Atomic force microscopy as a multifunctional molecular toolbox in nanobiotechnology. Nat Nanotechnol 3: 261-269.

125. Xiao J, Dufrêne YF (2016) Optical and force nanoscopy in microbiology. Nat Microbiol 1: 16186.

126. Gordon VD, Wang L (2019) Bacterial mechanosensing: The force will be with you, always. J Cell Sci 132(7): 227694. 
127. Morisaku T, Kido Y, Asai K, Yui H (2019) Mechanical properties of the coat protein layer and cortex in single Bacillus subtilis spores studied with an atomic force microscope and laser-induced surface deformation microscope. Anal Sci 35(1) :45-48.

128. Iturri J, Toca-Herrera JL (2017) Characterization of cell scaffolds by atomic force microscopy. Polymers (Basel) 9(8). E383.

129. Zolock RA, Li G, Bleckmann C, Burggraf LW, Fuller DC (2006) Atomic force microscopy of Bacillus spore surface morphology. Micron 27: 3639.

130. Dufrêne YF (2014) Atomic force microscopy in microbiology: New structural and functional insights into the microbial cell surface. MBio 5(4): e01363-e01314.

131. Chiorcea-Paquim AM,EritjaR, Oliveira-BrettAM (2018)Electrochemical and AFM characterization of G-quadruplex electrochemical biosensors and applications. J Nucleic Acids 2018: 5307106.

132. Benitez R, Toca-Herrera JL (2014) Looking at cell mechanics with atomic force microscopy: Experiment and theory. Microsc Res Tech 77(11): 947-958.

133. Xing Y, Li A, Felker DL, Burggraf LW (2014) Nanoscale structural and mechanical analysis of Bacillus anthracis spores inactivated with rapid dry heating. Appl Environ Microbiol 80(5): 1739-1749.

134. Cote CK, Bozue J, Moody KL, DiMezzo TL, Chapman CE, et al. (2008) Analysis of a novel spore antigen in Bacillus anthracis that contributes to spore opsonization. Microbiology 154: 619-632.

135. Fox A, Stewart GC, Wallera LN, Fox KF, Harley WM, et al. (2003) Carbohydrates and glycoproteins of Bacillus anthracis and related bacilli: Targets for biodetection. J Microbiol Meth 54: 143-152.

136. Chan JW, Esposito AP, Talley CE, Hollars CW, Lane SM, et al. (2004) Reagentless identification of single bacterial spores in aqueous solution by confocal laser tweezers Raman spectroscopy. Anal Chem 76: 599-603.

137. Evanoff DD, Heckel J, Caldwell TP, Christensen KA, Chumanov G (2006) Monitoring DPA release from a single germinating Bacillus subtilis endospore via surface-enhanced Raman scattering microscopy. J Am Chem Soc 128: 12618-12619.

138. Daniels JK, Caldwell TP, Christensen KA, Chumanov G (2006) Monitoring the kinetics of Bacillus subtilis endospore germination via surface-enhanced Raman scattering spectroscopy. Anal Chem 78 1724-1729.

139. Huang SS, De Chen, Patricia L Pelczar, Venkata Ramana Vepachedu, Peter Setlow, et al. (2007) Levels of Ca2+-dipicolinic acid in individual Bacillus spores determined using microfluidic Raman tweezers. J Bacteriol 189: 4681-4687.

140. Wang S, Doona CJ, Setlow P, Li YQ (2016) Raman spectroscopy and phase-contrast microscopy to characterize cold atmospheric plasma inactivation of individual bacterial spores. Appl Environ Microbiol 82(19): 5775-5784.

141. Boitor R, Sinjab F, Strohbuecker S, Sottile V, Notingher I (2015) Towards quantitative molecular mapping of cells by Raman microscopy: Using AFM for decoupling molecular concentration and cell topography Faraday Discussions 199-212.

142. Jung H, Kim DB, Gweon B, Moon SY, Choe W (2010) Enhanced inactivation of bacterial spores by atmospheric pressure plasma with catalyst TiO2. Appl Catal B-Environ 93.

143. Shintani H (2016) Inactivation of bacterial spore, endotoxin, lipid A, normal prion and abnormal prion by exposures to several sorts of gases plasma. Biocontrol Sci 21: 1-12.

144. López M, Calvo T, Prieto M, Múgica-Vidal R, Muro-Fraguas I, et al. (2019) A review on non-thermal atmospheric plasma for food preservation: mode of action, determinants of effectiveness, and applications. Front Microbiol 10: 622.

145. Hertwig C, Steins V, Reineke K, Rademacher A, Klocke M, et al. (2015) Impact of surface structure and feed gas composition on Bacillus subtilis endospore inactivation during direct plasma treatment. Front Microbiol 6: 774 .
146. Schlüter O, Ehlbeck J, Hertel C, Habermeyer M, Roth A, et al. (2013) Opinion on the use of plasma processes for treatment of foods. Mol Nutr Food Res 57(5): 920-927.

147. van Bokhorst-van de Veen H, Xie H, Esveld E, Abee T, Mastwijk H, et al. (2015) Inactivation of chemical and heat-resistant spores of Bacillus and Geobacillus by nitrogen cold atmospheric plasma evokes distinct changes in morphology and integrity of spores. Food Microbiol 45: 2633.

148. Reineke K, Langer K, Hertwig C, Ehlbeck J, Schlüter O (2015) The impact of different process gas compositions on the inactivation effect of an atmospheric pressure plasma jet on Bacillus spores. Innov Food Sci Emerg Technol 30: 112-118.

149. Klämpfl TG, Isbary G, Shimizu T, Li YF, Zimmermann JL, et al. (2012) Cold atmospheric air plasma sterilization against spores and other microorganisms of clinical interest. Appl Environ Microbiol 78: 5077 5082 .

150. Takamatsu T, Uehara K, Sasaki Y, Hidekazu M, Matsumura Y, et al (2015) Microbial Inactivation in the liquid phase induced by multigas plasma jet. PLoS ONE 10: e0132381.

151. Tseng S, Abramzon N, Jackson JO, Lin WJ (2012) Gas discharge plasmas are effective in inactivating Bacillus and Clostridium spores. Appl Microbiol Biotechnol 93: 2563-2570.

152. Ercan UK, Smith J, Ji HF, Brooks AD, Josh SG (2016) Chemical changes in nonthermal plasma-treated N-acetylcysteine (NAC) solution and their contribution to bacterial inactivation. Sci Rep 6: 20365.

153. Ricca E, Cutting SM (2003) Emerging applications of bacterial spores in nanobiotechnology. Journal of Nanobiotechnology 1(1): 6.

154. Minton NP (2003) Clostridia in cancer therapy. Nat Rev Microbiol 1(3): 237-242.

155. Bengtsson-Palme J, Kristiansson E, Larsson DG J (2018) Environmental factors influencing the development and spread of antibiotic resistance. FEMS Microbiology Reviews 42(1).

156. Uyen NQ, Hong HA, Cutting SM (2007) Enhanced immunisation and expression strategies using bacterial spores as heat-stable vaccine delivery vehicles. Vaccine 25(2): 356-365.

157. Roberts NJ, Zhang L, Janku F, Collins A, Bai RY, et al. (2014) Intratumoral injection of Clostridium novyi-NT spores induces antitumor responses. Sci Transl Med 6(249): 249ra111.

158. Heap JT, Theys J, Ehsaan M, Kubiak AM, Dubois L, et al. (2014) Spores of Clostridium engineered for clinical efficacy and safety cause regression and cure of tumors in vivo. Oncotarget 5(7): 1761-1769.

159. Sibley L, Reljic R, Radford DS, Huang JM, et al. (2014) Recombinant Bacillus subtilis spores expressing MPT64 evaluated as a vaccine against tuberculosis in the murine model. FEMS Microbiology Letters 358(2): 170-179.

160. Das K, Thomas T, Garnica O, Dhandayuthapani S (2016) Recombinant spore delivered $M$. tuberculosis antigens elicit immune response in mice. The Journal of Immunology 196(1 Supplement): 145-154.

161. Duc le H, Hong HA, Fairweather N, Ricca E, Cutting SM (2003) Bacterial spores as vaccine vehicles. Infection and Immunity 71(5): 2810-2818.

162. Farjadian F, Moghoofei M, Mirkiani S, Ghasemi A, Rabiee N, et al. (2018) Bacterial components as naturally inspired nano-carriers for drug/ gene delivery and immunization: Set the bugs to work? Biotechnology Advances 36(4): 968-985.

163. Paul C, Filippidou S, Jamil I, Kooli W, House GL, et al. (2019) Bacterial spores, from ecology to biotechnology. Adv Appl Microbiol 106: 79111.

164. Shoemaker WR, Lennon JT (2018) Evolution with a seed bank: The population genetic consequences of microbial dormancy. Evolutionary Applications 11(1): 60-75.

165. Tetz G, Tetz V (2017) Introducing the sporobiota and sporobiome. Gut Pathogens 9: 38. 
ISSN: 2574-1241

DOI: 10.26717/BJSTR.2019.20.003500

Andryukov BG. Biomed J Sci \& Tech Res

(c) (P) This work is licensed under Creative

Submission Link: https://biomedres.us/submit-manuscript.php

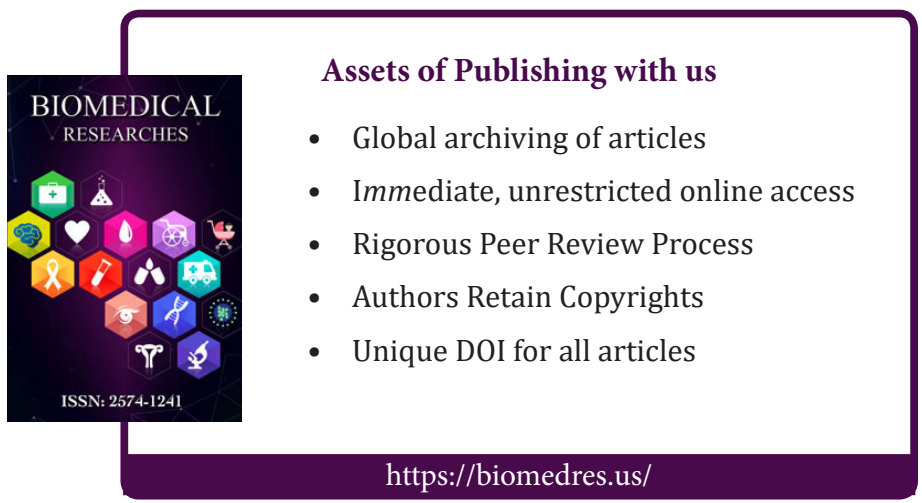

